\title{
Analysis on the Demand for Foreign Language Qualities and Training Strategies of Business Personnel in Linyi Trade City
}

\author{
Mei Yang \\ Feixian Campus, Linyi University, Linyi, Shandong, China \\ 15165569558@126.com
}

Keywords: Linyi trade city; Business personnel; Foreign language requirements; Training routes

\begin{abstract}
As a National Trade and logistics city and the core city in southern Shandong Province, Linyi adhere to fostering the development of new formats and enhancing the development of new power, pushing forward the internationalization of the mall. The smooth construction of overseas malls makes the foreign trade development more outstanding. Internationalization makes many business personnel improve their language literacy and skills. Getting across their requirement and creating corresponding training routes for them is necessary.
\end{abstract}

\section{Introduction}

Linyi Trade City started at the beginning of reform and opening-up,experiencing five phases, from Farmers' market stall formula to western suburbs of greenhouses, professional wholesale market, Linyi wholesale City and Linyi Commodity City over the past 30 years. Nowadays it has become the largest professional market cluster and an important logistics base in northern China, which Won the reputation "south Yiwu, north Linyi". [1]Along with the implement of " One Belt And One Road ", Linyi Trade City actively promote the construction of "Overseas malls" in Asia, Africa and other places, which of course will speed up the process of internationalization of Linyi Trade City. Linyi mall's market transactions in 2015 reached 3203.3 billion yuan, the year-on-year growth is $19.2 \%$. The total logistics was 5026.77 billion yuan, with a $23.9 \%$ year-on-year growth. Import and export volume reached 49.49 billion dollars. [2] The rapid development of business activities make more and more companies start to focus on training business personnel's foreign language to adapt to the current rapid pace of economic development.

\section{Demand for Foreign Language Qualities and Skills of Business Personnel.}

International Business personnel are mainly engaged in foreign trade activities, thus their foreign language qualities include basic foreign language skills, Intercultural communicative competence, abilities to learn and use foreign language vocabularies in international trade, professional foreign language vocabularies, basic knowledge of commodity importing countries' constitution and relevant laws[3]. Foreign language self-study ability is an important assessment in the selection and recruitment new employees in foreign-related enterprises, because business personnel's foreign language qualities will have a direct impact on the implement of business activities and expanding overseas markets.

After researching and investigating dozens of foreign-related enterprises including state-owned companies, private-owned companies, joint ventures and foreign-owned companies, we draw the conclusion that the demands for international business personnel's foreign language qualities are as follows:

Demand for Education Background and Professional Certification. According to the surveys, seventy-five percent companies require personnel with bachelor's degree. Three percent companies require employees with a master's degree or above. Thirty percent companies need English majored graduates with professional level eight certificates, and thirty-eight percent companies hope English 
majored graduates have passed TEM-4. Enterprises have put forward specific demands for non-English major graduates. Eight-nine percent companies require employees with a CET-4 Certificate, and a employee who have a CET-6 Certificate will be hired in priority. Data shows that companies engaged in international business activities want their staff with a bachelor's degree and English level requirements are not too high.

Foreign Language Skills Requirements. According to the survey, the importance degree of foreign language abilities the companies choose are ranked as follows: foreign language expression and communication skills (foreign language communicative competence), Business English writing ability, business interpretation and translation capability, cultural background of the partner countries, as well as business information reading and information gathering ability. From above we know that most companies focus on employees' foreign language expression and communication skills, and ability to solve problems through communication. While companies attach less importance to the terminology related to the industry. This is because each industry has its own terminology and it's unrealistic to require employees to master all walks of jargon. But it is worth noting that most of the staff signed up in the company need to receive business training, and this training will lay an important foundation for them to carry out business activities, which requires students have a good ability to learn. These qualities or skills may be obtained or improved through the repeated simulation experiments, training or other forms of experience. [4]

\section{Foreign Language Training Route of Business Personnel}

Foreign business activities in Linyi have developed rapidly, so more and more companies are starting to focus on its personnel's foreign language training in order to improve business communication. According to the researches, some business personnel didn't major in foreign language, the training aiming at this are diverse. Those below mentioned are the main training channels.

Market Training. Currently school principal training market is divided into the following categories: training class hold by school; enterprise training center; training class hold by organizations; training companies or individuals. Business personnel's training task is mainly undertook by some foreign language training institutions, which is usually short-term targeted training that is based on practical business language. This kind of training can increase personnel's language capacity rapidly as well as meet business personnel's urgent needs. These training are based on the premise of profit. In this case, training content, training time, training teachers or training sites will not be considered from the perspective of the trainee when the training cost is put in the first place. Such training is not very good for those who have specialized needs.

Enterprise Training. Such training is arranged based on business people's knowledge, skills that they should have on hand. Its characteristics are high targeted, stronger practical. Such training provide platforms for trainees to cultivate learning atmosphere so as to support and stabilize practical business foreign language training effect, thereby improve the overall level of trainees' foreign language levels. The training is normally offered by the relevant departments and enterprises themselves and do not require trainees to pay for it, so they do not have to worry about the expense. At the same time, enterprises can display their concern for employees' long-term development, which can also strengthen team cohesion. It will be better if the enterprises give the trainees the chance to have an oversea training especially those who have branches in western countries.

Needs can be defined as product-oriented and process-oriented, which have been explored by many researchers. Widdowson and Mountford explained the definition of product-oriented need. According to Mountford, needs means what the user-institution or society at large regards as necessary or desirable to be learnt from a program of language instruction [5]. Market training and enterprise training belong to this kind of training that can meet the process-oriented needs. 
Individual Acquisition. In contrast, process-oriented approach focus more on learners. Richterich believes that needs"consists primarily in compiling information both on the individuals or groups of individuals who are to learn a language and on the use which they are expected to make of it when they have learnt it" [6]. As a kind of process-oriented approach,individual acquisition has its own conditions, namely, self-learners themselves need to have some foundation in foreign language, have adequate learning materials, and they can make their own arrangements. Quite a number of business staff own individual acquisition conditions since they must use the foreign language to communicate in their working time. They can make use of every chance to self-study business foreign language to boost their foreign language level. But the realization of individual acquisition needs the creation of objective environment, the most of which is encouragement and incentives from the self-learners' companies. Besides that, self-learners interest in learning foreign language is the first factor, because of which determines the learners' attitude and learning effect in the future. [7]

The three above mentioned training routes can effectively improve business personnel's foreign language communicative abilities, among which job training is the most important and indispensable. But we may choose two or more routes according to the trainees' practical condition in order to achieve more progress.

\section{Effective Foreign Language Training Mode of Business Personnel}

No matter what kind of training route, the efficient training way is to start from the training mode that can effectively improve the training effect. Here three kinds of training modes are introduced in the following article. They are penetrating training mode, stealth training mode, and social participation mode.

Penetrating Training Mode. This kind of training mode is a highly effective mode which will become a trend in the future. It can be realized through intensive strengthening and practical application.

Talking about intensive strengthening, we mean that regular training services will be provided for the trainees at the unified time and the same place to solve their learning difficulties. Because of their job characteristics and marital status, it's a bitter difficult to implement this kind of training. Obviously family responsibilities shorten their learning time and energy. In addition to that, social activities will occupy a lot of time and the numerous social activities make them feel physically and mentally exhausted. All these factors make foreign language intensive training for business staff become extremely difficult. However, such intensive training has many advantages. An intensive training mode can guarantee the learners' regular participation in study, offer and create a good learning atmosphere for the trainees to discuss and learn from each other. Under the harmonious atmosphere, the trainees will achieve more progress. At the same time, it also provide communication platform for trainees to communicate and share unexpected commercial information which bring more sense of achievement.

In order to obtain more obvious learning effect, practical application training mode is recommended. It's a kind of mode that a subtle influence will be obtained through culture, entertainment, life and other perspectives which is called cultural immersion. As we know language ability is the basis of communicative competence, however, having the language ability doesn't mean that we have the communication ability because language cannot exist without specific cultural background. [8] In this way, cultural immersion is wanted. Though this model is relatively relaxed to carry out, we should not neglect the training objectives. Cultural immersion includes watching original English movies and TV shows video, listening to English songs, reading English novels or newspapers. [9] Compared with intensive training, though the learning effect is not so efficient and direct, it can more easily arouse learners' enthusiasm of learning a foreign language. Besides cultural immersion, writing diaries is 
another way of practical application. Insisting on writing foreign language journals is a good way to improve the writing skills.

Experiential Training Mode. In general, compared with penetration training mode, experiential training mode can bring out better effect, because this kind of training mode has the characteristics of lifestyle and contextualization that can promote trainees to feel the true test of the society, without feeling so huge pressure posed by work. So trainees can seriously and will actively participate in training and complete the training mission. Experiential training mode includes being a volunteer to participate in foreign-related activities (such as a guide), participate in foreign personnel birthday parties, participate in overseas travels, and so on. [10] Such kind of training can be an interesting business activity, or a casual chat with a foreigner which can not be restricted by geographical and environmental factors. In this way, training time and space is extended, and the influence on the trainees thinking is realized in a subtle way. With the advance of the city internationalization, Linyi has hosted many international competitions or activities such as International Marathon Race and CLITLF which has brought numerous chances and challenges for the participators.

\section{Summary}

The prosperity of Linyi international trade requires business personnel's high qualities including strong foreign language abilities. As we know that the improvement of business personnel's foreign language communication abilities cannot do without the various and numerous training. Comprehending the business personnel's desire and create appropriate training mode will promote the trainees growth, thus bring better economic benefits for their enterprises and in some way enhance the cohesion of the enterprises.

\section{References}

[1] Information on http://www.linyi.gov.cn

[2]Information on http://tech.gmw.cn/newpaper/2016-02/29/content 111218723.htm

[3] Y.M.Wang: Modern University Education,(2012)No.5, p.108.

[4] J.L.Jia: China Tendering,(2013)No.5, p.45.

[5] Mountford,A: The What, the Why and the Way(Longman Group, the U.K.1981), p27.

[6]Richterich,R:1983.Case Studies in Identifying Language needs (Pergamon press, the U.K.1983),p55.

[7] C.Z.Zhang:Journal of Campus\& Mental Health,Vol.8(2010)No.3, p.177.

[8] Y.G.Liu: Science Education,Vol.17(2011)No.3,p.32

[9] G.P.Wang:Theory Monthly,(2007)No.1,p.68

[10]M.Feng:Foreign Language and Literature,Vol.30(2014)No.1, p153. 